\title{
Surface Water Quality Monitoring in Nigeria: Situational Analysis and Future Management Strategy
}

\author{
A.M. Taiwo ${ }^{1}$, O.O. Olujimi², O. Bamgbose ${ }^{3}$ and T.A. Arowolo ${ }^{3 *}$ \\ ${ }^{1}$ Division of Environmental Health Risk Management, University of Birmingham, \\ ${ }^{2}$ Department of Chemistry, Cape Peninsula University of Technology, \\ ${ }^{3}$ Department of Environmental Management and Toxicology, \\ University of Agriculture, Abeokuta, \\ ${ }^{1}$ United Kingdom \\ ${ }^{2}$ South Africa \\ ${ }^{3}$ Nigeria
}

\section{Introduction}

Water is a finite resource that is very essential for the human existence, agriculture, industry etc. Without any doubt, inadequate quantity and quality of water have serious impact on sustainable development. In developing countries, most of which have huge debt burdens, population explosion and moderate to rapid urbanization, people have little or no option but to accept water sources of doubtful quality, due to lack of better alternative sources or due to economic and technological constraints to treat the available water adequately before use (Calamari and Naeve, 1994; Aina and Adedipe, 1996). The scarcity of clean water and pollution of fresh water has therefore led to a situation in which one-fifth of the urban dwellers in developing countries and three quarters of their rural dwelling population do not have access to reasonably safe water supplies (Lloyd and Helmer, 1992).

Assessment of water is not only for suitability for human consumption but also in relation to its agricultural, industrial, recreational, commercial uses and its ability to sustain aquatic life. Water quality monitoring is therefore a fundamental tool in the management of freshwater resources. To underpin its importance, World Health Organization (WHO), United Nations Environment Programme (UNEP), United Nations Educational, Scientific and Cultural Organization (UNESCO) and World Meteorological Organization (WMO) launched in 1977, a water monitoring programme to collect detailed information on the quality of global ground and surface water.

Monitoring can be conducted for the following five major purposes:

- characterize waters and identify changes or trends in water quality over time;

- identify specific existing or emerging water quality problems;

${ }^{*}$ Corresponding Author 
- gather information to design specific pollution prevention or remediation programs;

- determine whether program goals -- such as compliance with pollution regulations or implementation of effective pollution control actions -- are being met; and

- $\quad$ respond to emergencies, such as spills and floods.

Nigeria, the most populous country in Africa, has an area of $923,768 \mathrm{~km}^{2}$, and located between Latitudes $4^{\circ} 16^{\prime} \mathrm{N}$ and $13^{\circ} 52^{\prime} \mathrm{N}$, and Longitudes $2^{\circ} 49^{\prime} \mathrm{E}$ and $14^{\circ} 37^{\prime} \mathrm{E}$ (see Figure 1). It is stretched across dimensions of $1,200 \mathrm{~km}$ from east to west and 1,000 km from north to south (http://ramsar.wetlands.org/portals/15/nigeria.pdf). The space occupied by inland water bodies in Nigeria is estimated at $900 \mathrm{~km}^{2}$ (Ekiye and Zejiao, 2010) representing $0.1 \%$ of the total land mass while the coastal area stretched up to $853 \mathrm{~km}$ (comprising inshore waters, coastal lagoons, estuaries and mangrove especially in the Niger Delta (http://www. unep. org/AbidjanConvention/docs/the $\% 20$ status $\% 20$ of $\% 20$ the $\% 20$ nigerian $\% 20$ coastal $\% 20$ zones $\% 2$ 0version \%202.pdf). The total area occupied by water in Nigeria is $13,000 \mathrm{~km}^{2}$.

Nigeria has abundant water resources covering an enormous and diverse landscape, although they are unevenly distributed over the country (WHO/UNEP, 1997). The four major drainage systems in the Nigeria are:

- The Niger River Basin Drainage System with its major tributaries of Benue, SokotoRima, Kaduna, Gongola, Katsina-Ala, Donga, Tarabe, Hawal and Anambara Rivers.

- The Lake Chad Inland Drainage System comprising the Kano, Hadejia, Jama'are Misau, Komadougou-Yobe, Yedoseram and Ebeji Rivers.

- The Atlantic Drainage System (east of the Niger) comprising the Cross, Imo, Qua Iboe and Kwa Rivers.

- The Atlantic Drainage System (west of Niger) made up of the Ogun, Oshun, Owena and Benin Rivers.

Apart from the Lake Chad Drainage System, the remaining three drainage systems terminate in the Atlantic Ocean with an extensive network of delta channels (Figure 2).

The natural quality of rivers and streams at any point reflects the quality of upstream contributions of surface run-off and groundwater discharge. The various water bodies in the country are used for various purposes such as fishing, transportation, sand mining, irrigation, recreation, abstraction for industrial and domestic purposes as well as electric generation.

Urbanization, intensive agriculture, recreation, and the manufacturing industry are affecting water quality throughout the world. Available literature on environmental monitoring of surface water indicated that streams and rivers in the country are showing increasing trend of water pollution due to increase population, industrialization and urbanization. Waste generations by the industries and households have continued to increase. These wastes are indiscriminately disposed-off into the water bodies. This has led to pollution of inland water bodies and coastal waters and subsequently increased water quality parameters such as heavy metals, nutrients and organic matter, soluble ions, oil and grease, and organic chemicals such as pesticides and poly-nuclear aromatic hydrocarbons (PAHs), (Esoka and Umaru, 2006; Adebayo et al., 2007; Jaji et al., 2007; Mashi and Alhassan, 2007; Solomon, 2009). Urgent attention is therefore necessary to mitigate water pollution problems in Nigeria through monitoring as well as enforcement of emission standards by industries (Ekiye and Zejiao, 2010). 
Surface Water Quality Monitoring in Nigeria:

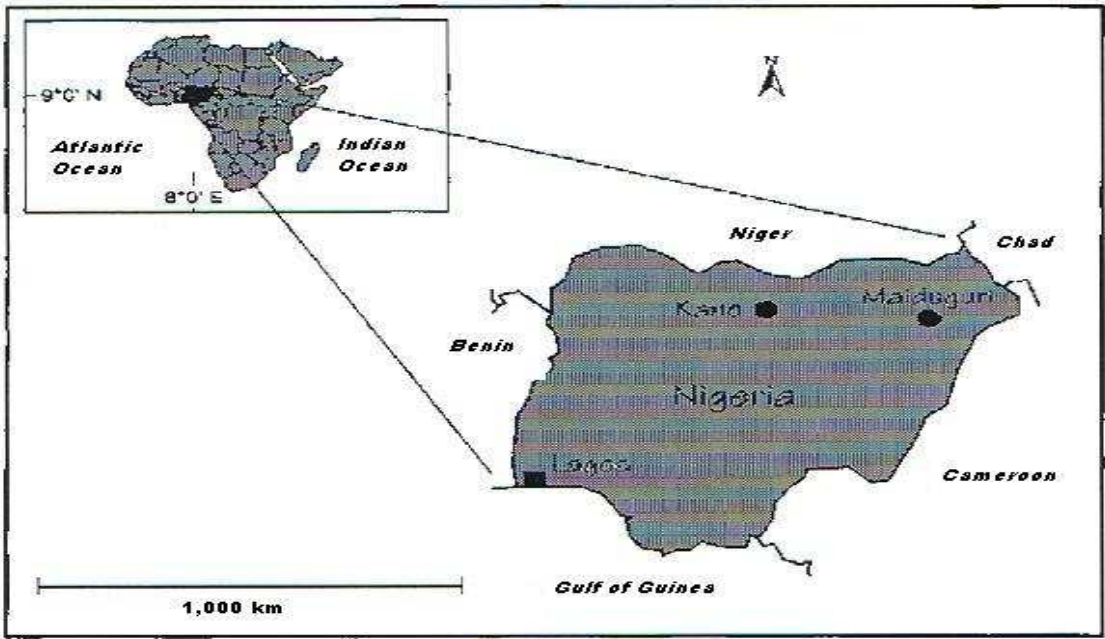

Fig. 1. Location map of Nigeria

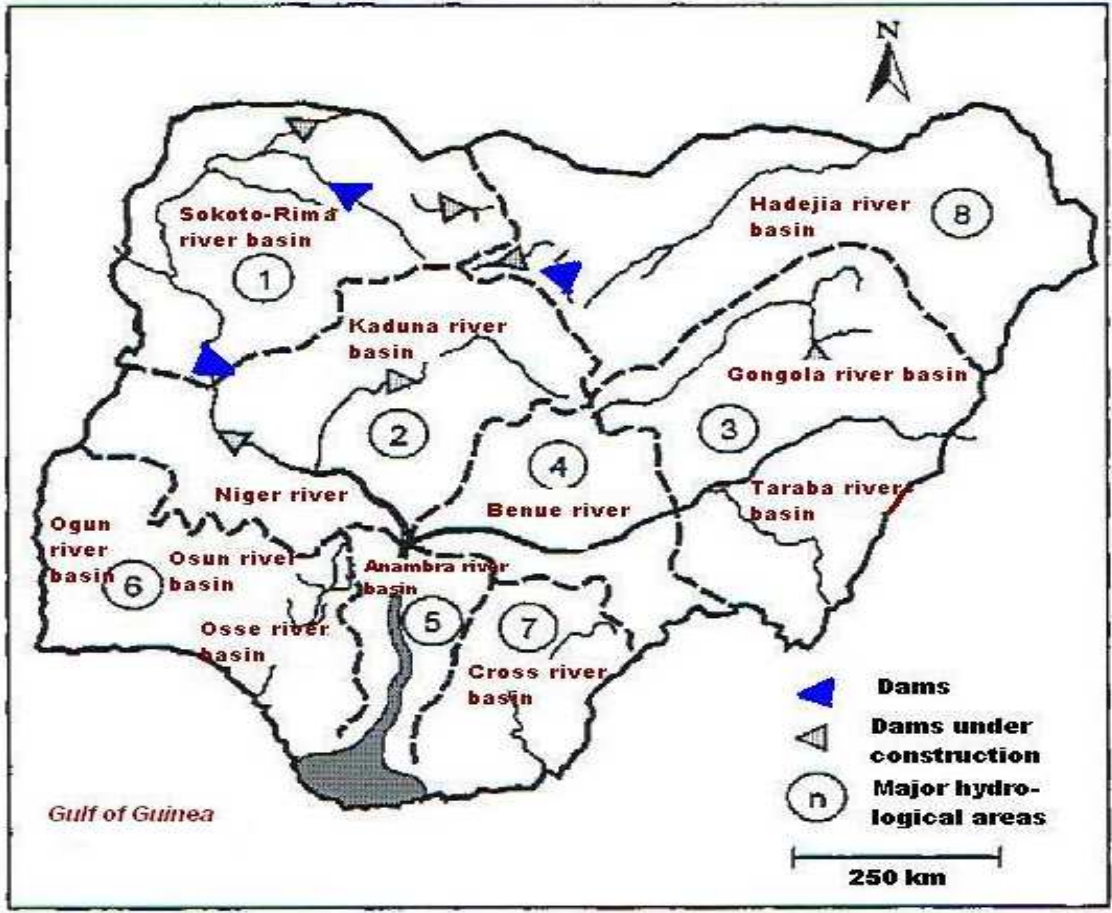

Fig. 2. Map of Nigeria showing major rivers and hydrological basins: 1 Niger North, 2 Niger Central, 3 Upper Benue, 4 Lower Benue, 5 Niger South, 6 Western Littoral, 7 Eastern Littoral, 8 Lake Chad (WHO/UNEP, 1997). 
According to National Bureau of Statistics (2009), at least 27\% Nigerians depended absolutely on streams, pond, river and rainwater for their drinking water source. Research has shown high prevalence of waterborne diseases such as cholera, diarrhoea, dysentery, hepatitis etc. among Nigerians (Oguntoke et al., 2009; Raji and Ibrahim, 2011). The need for water quality monitoring is paramount to safeguard the public health and also to protect the water resource in Nigeria. To emphasise the importance of environmental monitoring in Nigeria, the then Federal Environmental Protection Agency (FEPA) - now Federal Ministry of Environment and National Water Resources Institute (NWRI) organised a National Seminar on "Water Quality Monitoring and Environmental Status in Nigeria" between October 16 to 18, 1991. The proceeding of this National Seminar was published by FEPA in 1996 (Aina and Adedipe, 1996). The major objective of this paper is to assess the current situation of surface water quality monitoring in Nigeria two decades after the FEPA/NWRI National Seminar and provide future management strategy that may be adopted by the authorities. Certainly, information concerning the water quality of our rivers will provide a useful instrument for policy makers to formulate management strategy for control and abatement of water pollution.

\section{Sources of water pollution in Nigeria}

\subsection{Industrial discharges and oil spills}

Studies carried out in most cities in Nigeria had shown that industrial effluent is one of the main sources of surface water pollution in Nigeria (Ekiye and Zejiao, 2010). Industrial effluents when discharged directly into the rivers without prior treatment have capacity of increasing water quality parameters. Dada (1997) indicated that less than $10 \%$ of industries in Nigeria treat their effluents before being discharged into the rivers. This has led to high load of inorganic metals such as $\mathrm{Pb}, \mathrm{Cr}$ and $\mathrm{Fe}$ in most of water bodies (Ahmed and Tanko, 2000; Wakawa et al., 2008). Table 1 shows the results of physico-chemical parameters of effluents collected from some industries in Lagos, Kaduna and Port Harcourt. Most of the results were higher than the permissible limits set by FEPA (1991). The resultant effects of this will be on the receiving streams and rivers. The impacts could include water quality impairment, reduction in fish abundance and effect on water-usage for recreation, industrial and domestic purposes. High phosphate concentrations in these effluents could result into nutrient enrichment of the receiving water bodies thereby leading to ecological disaster. Metal pollution of Warri River by industrial discharges has been reported by Ayenimo et al. (2005). The River was monitored for heavy metals such as $\mathrm{Fe}, \mathrm{Cu}, \mathrm{Ba}, \mathrm{Pb}, \mathrm{Cd}, \mathrm{Cr}, \mathrm{Ni}$ and $\mathrm{Co}$. Results showed elevated values of these metals at sampling point located near an industry. Correlation analysis of the metals also suggested common source. Other water quality parameters showed elevated values indicating pollution by the nearby industry.

The activities of the oil industries in the Niger-Delta region of Nigeria have impacted negatively on the surface water quality around the area. This has led to water scarcity, disruption of socio-economic activities and poor aesthetic quality of most of the water bodies polluted by the oil spills (Egborge, 1994). Most of the rivers around the Niger-Delta region of the country could not be abstracted for treatment for drinking purpose because of pollution by crude oil. The impact of oil activities in these areas had done much havoc to the environment of this region most especially on the water resources. 


\begin{tabular}{|c|c|c|c|c|c|}
\hline $\begin{array}{l}\text { Effluent } \\
\text { Parameters }\end{array}$ & (Adel & $\begin{array}{l}\text { gos } \\
\text { yo et al., } \\
07 \text { ) }\end{array}$ & $\begin{array}{c}\text { Kaduna } \\
\text { (Yusuf and } \\
\text { Shonibare, } \\
\text { 2004) }\end{array}$ & $\begin{array}{c}\text { Port } \\
\text { Harcourt } \\
\text { (Ajao and } \\
\text { Anurigwo, } \\
2002)^{*}\end{array}$ & $\begin{array}{c}\text { FEPA } \\
(1991) \\
\text { standard }\end{array}$ \\
\hline Temperature $\left({ }^{\circ} \mathrm{C}\right)$ & 27.6 & 30.3 & 30 & & $<40$ \\
\hline Color (CTU) & & & 2400 & & \\
\hline $\mathrm{pH}$ & 7.6 & 4.8 & & & $6-9$ \\
\hline Conductivity $\left(\mathrm{mS} \mathrm{cm}^{-1}\right)$ & 761 & 1156.6 & & & \\
\hline Turbidity (NTU) & 11.6 & 573.6 & & & \\
\hline Salinity (\%) & 0.1 & 0.5 & & & \\
\hline Alkalinity (mg L-1) & 766.6 & 445 & & & \\
\hline Free Chlorine (mg L-1) & & & 0.5 & & \\
\hline Nitrate (mg L-1) & & & 4.0 & 362 & 20 \\
\hline Ammonia (mg L-1) & & & 1.0 & & \\
\hline Phosphate (mg L-1) & & & 1.0 & 836 & 5 \\
\hline Total Hardness (mg L-1) & 1233.3 & 4083.3 & & & \\
\hline TSS (mg L-1) & 320 & 833.3 & 400 & 3533 & 30 \\
\hline TDS (mg L-1) & & & 1100 & & 2000 \\
\hline Oil and Grease (mg L-1) & 20 & 0.0 & 7.0 & 2343 & 10 \\
\hline BOD (mg L-1) & 534 & 1352.3 & 300 & 4374 & 30 \\
\hline $\mathrm{COD}\left(\mathrm{mg} \mathrm{L}^{-1}\right)$ & 850 & 2253 & 1800 & & \\
\hline $\mathrm{H}_{2} \mathrm{~S}\left(\mathrm{mg} \mathrm{L}^{-1}\right)$ & 17.2 & 130 & 0.6 & & \\
\hline
\end{tabular}

* Total effluent discharge from observed industries, TSS-total suspended solids, TDS-total dissolved solids, BOD-biochemical oxygen demand, COD-chemical oxygen demand, DO-dissolved oxygen (Data adapted from Ekiye and Zejiao, 2010).

Table 1. Effluent analysis of some industrial discharges in Nigeria

\subsection{Municipal and agricultural wastes}

Waste management is a major problem in most developing nations of the world including Nigeria (Taiwo, 2011). Indiscriminate disposal of municipal wastes remains a major threat to surface water pollution in Nigeria. In most cases, sewage and waste water from homes are routed into the rivers and streams. Jaji et al. (2007) found elevated water quality parameters in some sampling locations of Ogun River. These were partly attributed to the activities of abattoir located close to the River at a notable market in Abeokuta metropolis. The work of Arimoro et al. (2007) on the impact of sawmill activities on the water quality of River Benin reported high BOD and low DO values at the discharge point of the wastes into the River.

The impact of point source pollution from sewage treatment oxidation pond on a receiving stream was studied by Ogunfowokan et al. (2005). The researchers observed significant elevation of water indices such as $\mathrm{pH}, \mathrm{BOD}$, nitrate, phosphate and TSS. It is well known that oxygen depletion in water bodies could cause fish death while increase in BOD signifies high load of organic matter. Also, organic matter decomposition in surface water produced inorganic nutrients such as ammonia, nitrate and phosphorus with resultant effects of eutrophication and other serious ecological problems of such water body (Ogunfowokan et 
al., 2005). Taiwo (2010) has also observed high water quality parameters of a stream in Abeokuta due to direct discharge of poultry wastes into the stream. The use of pesticides and fertilizer for bumper food production is a well known policy of several Governments all over the world. However, agriculture remains the major source of nitrate and phosphate pollution of surface water. Nitrate in drinking water is detrimental to infant health due to the disease known as methemoglobineamia (Taiwo, 2010).

\subsection{Urban run-off}

Urbanization in most Nigerian cities has resulted in the concentration of large population in some areas living under poor sanitation conditions (Olade, 1987). This invariably has led to increased waste generations with heaps of waste everywhere. During rainfall, some of these wastes are washed into the poor drainage systems and subsequently, into nearby rivers (Taiwo et al. 2011). Lack of town planning principles and strategies in Nigeria's cities and towns had aggravated the risks of urban run-off with resultant effect on surface water. The poorly managed drainage system in the country had caused the surface water impairment due to erosions during rainfall. Rainfall runoff carries all sorts of pollutants from houses, industries, farmland and dumping sites. Research has shown that some of the water quality parameters of both ground and surface water often rise up during rainfall with high values of turbidity, solids and anionic species often been recorded (Jaji et al., 2007; Mustapha, 2008; Taiwo, 2010; Taiwo et al., 2011). The effect of urban run-off has been studied on the Epie Creek in the Niger Delta by Izonfuo and Bariweni (2001). The impact of human activities around the Creek was felt on the water body as low DO values were recorded during the wet season due to urban run-off.

Agricultural run-off of pesticides, plant and animals wastes is also a major contributing source of organic pollution to water bodies in Nigeria. The work of Mustapha (2008) had linked the periodic eutrophication of Oyun Reservior in Offa, Kwara state to run-off of phosphate fertilizers from nearby farms in addition to cow dungs washing from the watershed into the Reservoir. Water pollution through surface run-off has been reported in literatures with subsequent effects on nutrient enrichment, water quality impairment, marine lives spawning ground destruction and fish kill (Martin et al., 1998; Izonfuo and Bariweni, 2001).

\section{Water quality of rivers in Nigeria}

Figure 3 shows some important rivers in Nigeria while Table 2 shows the results of physicochemical parameters of some of these rivers which have been monitored by several researchers in the country.

High TSS found in rivers in Nigeria has tendency of reducing the light penetration into the river leading to a reduced photosynthesis with consequent effects on both phytoplankton and zooplankton populations of the aquatic environment. A study by Ajibade (2004) has shown high TSS values in Asa River (Kwara state) while Osibanjo et al. (2011) has also reported similar findings for Rivers Ona and Alaro in Ibadan. Harrod and Theurer (2002) in a similar study reported that high TSS concentration could cause a reduced development and survival of salmonid eggs and larvae. Clogging of TSS on fish gills could also result into stress, reduced growth, suppressed-immune system leading to increased susceptibility to 
disease and osmotic dysfunction and death (Bilotta and Brazier, 2008). Elevated values of TSS are capable of shielding harmful organisms in drinking water (Taiwo et al., 2011). TSS could also act as a vector of nutrients such as phosphorus (Heathwaite, 1994), and toxic compounds such as pesticides and herbicides from the land surface to the water body (Kronvang et al., 2003) leading to proliferation of phytoplankton in rivers. In surface water, TSS could cause drift in invertebrate population (Bilotta and Brazier, 2008).

Another notable water quality characteristic of rivers in Nigeria is high turbidity. Turbidity values reported for most rivers in Nigeria were far greater than 5.0 NTU limit given by WHO (2008) (Table 2). Ajibade (2004), Adefemi et al. (2007) and Wakawa et al. (2008) have also reported elevated turbidity values in rivers in Nigeria. This could be linked to run-off effects as well as domestic and industrial discharges on the rivers.

Low BOD and COD values have been reported in New Calabar River and Kubanni River in Kaduna. However, a high BOD and COD values have been observed for Challawa River in Kano State with mean concentrations ranging between 10 to $30 \mathrm{mg} \mathrm{L}^{-1}$ and 170 to $260 \mathrm{mg} \mathrm{L}^{-1}$ respectively (Wakawa et al., 2008). Very low DO values (2.67-3.30 $\mathrm{mg} \mathrm{L}^{-1}$ ) were also observed in Challawa River. Pollution of the rivers was directly linked with the industrial effluent discharges. Osibanjo et al. (2011) also reported high COD values for the water samples from Rivers Ona and Alaro. The authors attributed these to leachate from dumpsites, agricultural and urban runoffs.

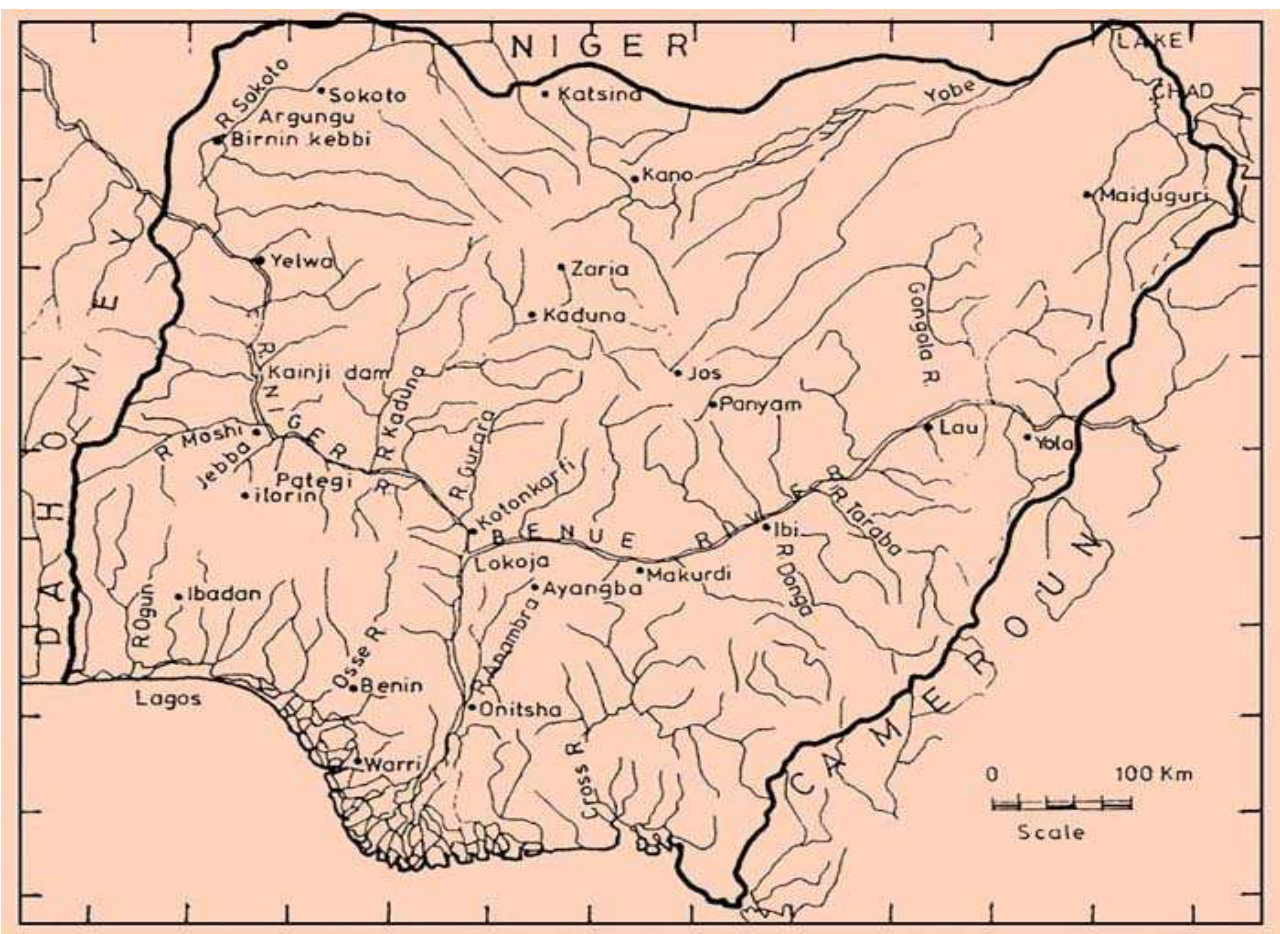

Fig. 3. Map showing rivers in Nigeria. 
Nutrient enrichment is predominant in most rivers in Nigeria. The values of nitrates and phosphate depicted by authors in Table 2 were low. But reports by other authors on some rivers indicated high nutrient load of most rivers in Nigeria. For instance, Olajire and Imeokparia (2001) observed high concentrations of nitrate, ammonia and phosphate in Osun River, a consequence of human activities. Human activities observed along the study area include agricultural land-use, anthropogenic activities and industrialization. Farming operations around the area were said to have contributed immensely to elevated values of ammonia and phosphate (Olajire and Imeokparia, 2001). Edet and Worden (2009) assessed the seasonal and tidal effects on the physical parameters of river and groundwater in Calabar, Nigeria. The researchers reported a significant seasonal effect on temperature, redox potential (Eh), and DO in the river water. They also observed that a significant tidal influence existed on DO in both river-and groundwater. Comparison between groundwater and river water showed statistically significant difference in EC, TDS, Eh, DO, $\mathrm{Na}, \mathrm{Cl}^{-}$and $\mathrm{NO}_{3}{ }^{-}$. The significant differences in EC, TDS, $\mathrm{Na}$ and $\mathrm{Cl}^{-}$were attributed to tidal flushing; the difference in Eh was due to geology of the area while $\mathrm{NO}_{3}^{-}$was as a result of anthropogenic pollution. The study concluded that tidal flushing, anthropogenic effects and oxygen supply during recharge contribute to the shaping of water chemistry in the area.

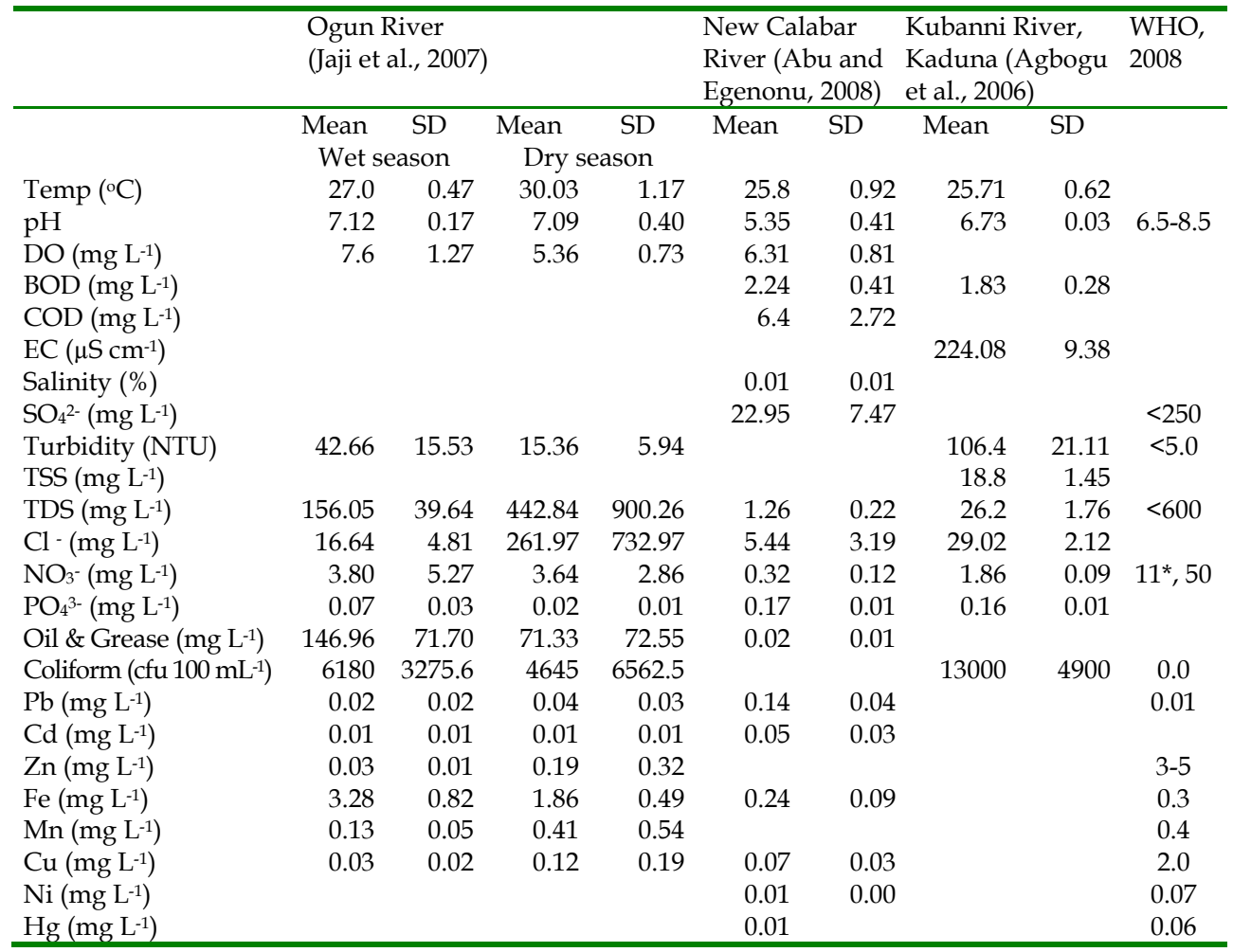

SD-standard deviation (original data from the literatures have been subjected to simple descriptive statistics).

Table 2. Mean concentration of water quality parameters of some Rivers in Nigeria 
Metal pollution of some rivers in Nigeria may be due to industrial discharges, corrosion of iron and steel materials in building, leachates from dumpsites and vehicles etc (Jaji et al. 2007). Fe concentrations in most Nigeria's rivers are usually greater than WHO standard of $0.3 \mathrm{mg} \mathrm{L}^{-1}$ in drinking water (Offiong and Edet, 1996). High $\mathrm{Pb}$ concentration in some surface water samples have been attributed to the use of leaded petrol in vehicles. Taiwo (2010) found elevated values of lead at a sampling site of Alakata stream in Abeokuta. High lead level in surface water may also be due to vehicular deposition. Dry deposition of particulate lead on water bodies is capable of increasing $\mathrm{Pb}$ level of surface water. Lead is a potential killer especially in children. In some villages in Gummi and Bukkuyum Local Government area of Zamfara state, more than 400 deaths were reported due to lead poisoning (Galadima et al., 2011). Heavy metals are potential threats to the environment and ecosystem due to their persistence and bio-accumulation in food chain.

The presence of oil and grease on the surface of water bodies in Nigeria is a sign of pollution which may have serious effect on the aquatic ecosystem of the nation. Oil and grease is toxic to aquatic organisms in general and also capable of reducing dissolved oxygen. Between 1997 and 2001 in the Niger Delta region of Nigeria, 2,097 oil spill incidents were recorded (Nwilo and Badejo, 2005). The activity of oil exploitation and refining has reduced the water quality of Nigeria's river in the Niger Delta region. The mangrove ecosystem along the coastal areas of the Niger Delta has been wantonly destroyed by oil spills (Nwilo and Badejo 2005). Besides the oil region of Niger Delta, which is synonymous with oil spill pollution, elevated levels of oil and grease have been reported by Osibanjo et al. (2011) at the downstream of Rivers Ona and Alaro in Ibadan, South-western Nigeria. The authors attributed these to urban run-off from auto repair workshop and petroleum depot.

The high values of coliform reported for some river water samples confirm faecal pollution from domestic sewage, dumping sites, abattoir activities etc. High coliform values are typical characteristics of many rivers in Nigeria. For instance, high population of faecal coliform counts has been reported in Ikpoba River, Edo state of Nigeria by Tatah and Ikenebomeh (1999). Similarly, Nwankwu (1992) also reported coliform values in the range of 3100-150, $000 \mathrm{cfu} 100 \mathrm{~mL}^{-1}$ at Iddo area of the Lagos lagoon. The high population of these microbial pollutants was linked to contaminations from the dumpsites around the Lagoon. Pollution of surface water in Nigeria therefore calls for great attention. Some people see water body as medium for waste disposal. Feacal pollution of rivers in Nigeria signifies poor sanitation management as well as unhygienic manner of living among people, especially those living close to the riverine areas.

It has also been observed that pathogenic contamination of Nigeria's rivers comes from aquaculture practices involving fertilization of ponds with cow and poultry manures; and direct dumping of faecal matters into the rivers (Obasohan et al., 2010). Presence of microbial pollutants in drinking water could pose risks to public health of waterborne diseases such as cholera, diarrhoea, hepatitis, dysentery, poliomyelitis, typhoid etc.

Meinhardt (2006) has highlighted susceptible population to waterborne diseases to include pregnant women, children, immune-suppressed individuals, geriatric patients and patients with pre-existing clinical disorders and chronic diseases. Nearly 40,000 cases cholera epidemic were reported in 11 states in Nigeria from January-October 2010, out of which 1,500 people were confirmed dead (Adewara and Visser, 2011). Diarrhoea is the second 
largest cause of children's mortalities in Nigeria according to Water Initiative (2010). Nigerian children of age less than 5 years make up $17 \%$ of the total annual deaths of 1.8 millions being recorded globally due to poor sanitation (Water Initiative, 2010).

\section{Organic pollutants monitoring in Nigeria freshwater systems}

Unlike inorganic pollutants and pathogens monitoring in Nigeria water systems, organic pollutants monitoring had suffered major neglects in terms of qualitative and quantitative monitoring. Due to poor institutional funding by the Nigeria governments, studies on the levels of polynuclear aromatic hydrocarbons (PAHs) and other organic contaminants in the country are very scanty. Until recently, most studies on organic compounds dates back to the 1970's and 1980's when there was some equipment and little funding to conduct research. The poor funding had resulted in poor human resources base coupled with lack of instrumentation to monitor the level and distribution of these organic pollutants in the environment.

Despite these challenges, few studies had recently reported some levels of PAHs in the Nigeria water systems. PAHs have been listed as priority pollutants that need to be monitored in both industrial and domestic effluents and freshwater systems (Emoyan, 2009). The health impacts of PAHs include carcinogenic, cardiovascular, bone marrow and liver toxicity. Emoyan (2009) reported the concentration range of 0.2309 to $1.0468 \mathrm{mg} \mathrm{L}^{-1}$ for PAHs in surface water due to contamination from Kokori-oil field in the Niger-Delta. Fluoren was the dominant of the 16 PAHs priority pollutants investigated. The source of water contamination was identified to be mainly petrogenic. The reported concentrations were higher than the CCME (2008) and the Netherland MPC guidelines. In addition to PAHs, another important set of organic pollutants are pesticides. Pesticides are highly toxic, synthetic organic compounds that are widely used in agriculture and the industries (Adeboyejo et al., 2011; Adeyemi et al., 2011). Pesticides usage in Nigeria had soared in the past decades such that over 21 different types of organophosphates, organochlorine and carbamates insecticides have been introduced into the Nigeria market. Out of the broadly classified pesticides, organochlorine pesticides (OCPs) constitute the most widely used for agricultural purposes despite their ban in other countries (Bouman, 2004; Blaso et al., 2005; Ize-Iyamu et al., 2007; Adeyemi et al., 2011).

Organochlorine pesticides are known to be very stable, resistant to natural breakdown, liposoluble compounds that are capable of bioaccumulation and biomagnifications in the fatty parts of biological organisms (Adeyemi et al., 2011). The health effects of pesticides in man and animals include immune systems malfunction, endocrine disruption, breast cancer, irritation, dizziness, tremor, toxic and chronic convulsion (Ize-Iyamu et al., 2007; Ezemonye et al., 2009; Adeboyejo et al., 2011; Adeyemi et al., 2011). Like PAHs, studies on OCPs are very few. Pesticides unlike other organic compounds may enter ground water and surface water as run-off due to direct application to the soil surface or application to crops for destroying, preventing, repelling or mitigating against pests, animals, fungi and microorganisms (Ware and Whitacre, 2004; Ezemonye et al., 2009). Other sources of pesticides entrance into water bodies includes through point sources like sewage treatment plants, sewer overflows and poor management practices of farmers or from atmospheric deposition (Guruge and Tanabe, 2001; Mayon et al., 2006; Shukla et al., 2006). 
In a recent study, Ezemonye and co-workers (2009) reported concentration ranges of diazinon (organophosphate insecticide) in water, sediment and fish samples from Warri River in Niger-Delta after extraction and quantification using high pressure liquid chromatography. The concentration range of 0.07 to $1.76 \mu \mathrm{g} \mathrm{L}^{-1}, 0.49$ to $2.54 \mu \mathrm{g} \mathrm{L}^{-1}$ and 0.08 to $4.29 \mathrm{\mu g} \mathrm{L}^{-1}$ were reported for water, sediment and fish samples, respectively. Ize-Iyamu et al. (2007) investigated and reported seven OCPs namely lindane, aldrin, pp-DDE, pp-DDD, opDDD, op-DDT and pp-DDT in water and two fish species (Tilapia Zilli and Claras lazera) from Ikoro, Ovia and Ogba rivers using gas chromatography - electron capture detector. Lindane and aldrin were the most dominant OCPs in all the samples analyzed ranging from 0.5712 to $0.8143 \mu \mathrm{g} \mathrm{L}^{-1}$ and 0.5031 to $0.3218 \mu \mathrm{g} \mathrm{L}^{-1}$, respectively.

In a more recent study on Lagos Lagoon, Adeyemi et al. (2011) reported the levels of nine OCPs residue in water using solid-phase extraction followed by gas chromatography quantification. The concentration range for the nine OCPs are 0.006 to $0.950, \mathrm{ND}$ to 0.067 , ND to $0.123,0.015$ to $0.774,0.015$ to $0.996,0.012$ to $0.910,0.005$ to $0.477,0.015$ to 0.996 and 0.080 to $0.790 \mu \mathrm{g} \mathrm{L}^{-1}$ for chlordane, heptachlor, methoxychlor, hexachlorobenzene, endosulfan, dichelorophenyltrichloroethane, dichelorophenyldichloroethylene, dieldrin and aldrin, respectively. In another study on the Lagos lagoon, Adeboyejo et al. (2011) found the following range of OCPs in water samples: aldrin (ND - $\left.658 \mathrm{ngl}^{-1}\right)$, chlordane (218.0 - 702.0 ng L-1), endrin (ND - $\left.2551 \mathrm{ng} \mathrm{L}^{-1}\right)$, DDD (20.3 - $\left.268 \mathrm{ng} \mathrm{L}^{-1}\right)$, pp-DDE (0 - $\left.176 \mathrm{ngl}^{-1}\right)$, a-HCH (ND - $\left.2300 \mathrm{ngl}^{-1}\right), \gamma-\mathrm{HCH}\left(\mathrm{ND}-783 \mathrm{ngl}^{-1}\right), \beta-\mathrm{HCH}\left(28.9\right.$ - $\left.518 \mathrm{ng} \mathrm{L}^{-1}\right), \delta-\mathrm{HCH}\left(0-498 \mathrm{ng} \mathrm{L}^{-1}\right)$, endosulfan (ND - $3726 \mathrm{ng} \mathrm{L}^{-1}$ ) and heptachlor (ND - $1405 \mathrm{ng} \mathrm{L}^{-1}$,).

Also, some levels of OCPs have been reported in edible aquatic life in the Lagos lagoon. Adeboyejo et al. (2011) reported OCPs concentration ranges of ND to 30240, ND to 517, 26 to 5480, ND to 11430, ND to 37780, ND to 13260, ND to 13, 0 to 3510, ND to 11490, 0 to 55740, ND to 990,38 to 421,0 to 1030 and ND to $60.3 \mu \mathrm{g} \mathrm{kg}-1$ for aldrin, dieldrin, chlordane, endrin, endosulfan, heptachlor, $\mathrm{HCB}, \mathrm{a}-\mathrm{HCH}, \gamma-\mathrm{HCH}, \beta-\mathrm{HCH}, \delta-\mathrm{HCH}, \mathrm{pp}-\mathrm{DDD}, \mathrm{pp}-\mathrm{DDE}$ and DDT, respectively.

Another group of organic pollutants of total neglect in the fresh and marine water systems are chemicals specifically classified as endocrine disruptors. According to DiamantiKandarakis et al. (2009), "an endocrine-disrupting substance is a compound, either natural or synthetic, which through environmental or inappropriate developmental exposures alters the hormonal and homeostatic systems that enable the organism to communicate with and respond to its environment." Endocrine disrupting chemicals (EDCs) consist of many natural and synthetic organic compounds, but are mostly manmade products such as alkylphenols, alkylphenols-ethonylates, and polychlorinated biphenyls (PCBs). Others include polychlorinated dibenzo-p-dioxins, polychlorinated dibenzofurans, organochlor pesticides, dichlorodiphenyl, dichloroethylene, nonylphenols, steroid hormones and phthalates (Arditsoglou and Voutsa, 2008; Hjelmborg et al., 2006; Mauricio et al., 2006). Of these groups of chemicals are Phthalates or phthalic acid esters (PAEs). They are diakyl or alkyl esters of 1,2 benzene carboxylic acid (Luks-Betlej et al., 2001; Alatriste-Mondragon et al., 2003; Adeniyi et al., 2008). They are formed when methanol, ethanol or other alcohols react with the carboxyl groups on the benzene ring of phthalic acids. The corresponding esters are formed with different alkyl chains, e.g., dimethyl phthalate (DMP), dibutyl phthalate (DBP) and di (2-ethylhexyl) phthalate (DEHP). Similar to other organic contaminants, EDCs are not been monitored in the freshwater systems to the best of our 
knowledge until recently when levels and the distribution pattern of phthalate esters were reported in some water samples from south western Nigeria.

Fatoki and Ogunfowokan (1993) reported PAEs concentrations in the river and tap water in the south western Nigeria. Water samples from the Lagos, Oyo, Osun, Ondo, and Delta states of Nigeria and the cities' water treatment plants were analyzed for the presence of phthalate esters. Extraction with $\mathrm{CHCI}_{2}$ and liquid chromatography was used for compound separation. Several phthalate esters, dimethyl- (DMP), diethyl- (DEP), and di-n-butyl- (DBP) were found present at levels of $10 \mathrm{mg} \mathrm{L}^{-1}$ to $1472 \mathrm{mg} \mathrm{L}^{-1}$ in river water and $91 \mathrm{mg} \mathrm{L}^{-1}$ to 1219 $\mathrm{mg} \mathrm{L}^{-1}$ in tap water from the cities' water treatment plants.

Ogunfowokan et al. (2006) investigated the levels and seasonal variations in the occurrence of PAEs in sewage oxidation pond at the Obafemi Awolowo University, Ile-Ife, Nigeria. The sewage lagoon and the receiving stream were grossly polluted as several phthalate ester plasticizers: dimethyl phthalate (DMP), diethyl phthalate (DEP), di-2-propyl heptyl phthalate (DPHP), dibutyl phthalate (DBP), diethyl hexyl phthalate (DEHP), di-octyl phthalate (DOP) and diisononyl phthalate (DINP) were found present at monthly mean levels of between 24.02 and $139.25 \mathrm{mg} \mathrm{L}^{-1}$ in the sewage treatment lagoon and 10.41 and $80.53 \mathrm{mg} \mathrm{L}^{-1}$ in the receiving stream. The results showed higher levels of phthalate esters in the sewage lagoon compared to the receiving stream. The sewage lagoon was identified as a pollution point source into the receiving stream. Levels of phthalates obtained from the receiving stream are much higher than the water criteria of $3 \mu \mathrm{g} \mathrm{L} \mathrm{L}^{-1}$ phthalates recommended by the United States Environmental Protection Agency (USEPA) for the protection of fish and other aquatic life in water and the Suggested No-Adverse Effect Levels (SNAEL) of 7.5-38.5 $\mu \mathrm{g} \mathrm{L}^{-1}$ for drinking water. This should give cause for great environmental concern. Peoples' health downstream is at stake and so is the 'health' of the ecosystem.

In a more recent study on this group of compounds, Adeniyi et al. (2011) reported four phthalate esters - DMP, DEP, DBP and DEHP - in water, sediment, and some fish species using flame ionization gas chromatography. The samples were collected from the Ogun river catchments, Ketu, Lagos. The DMP was not detected in the water and fish samples but was detected in sediments collected from four of the six sampling sites. The concentration of DEP,DBP, and DEHP in the fish species ranged from 320.0-810.0, 380.0-1,080.0, and 40.0$150.0 \mu \mathrm{g} \mathrm{kg-1}$ in Tilapia sp.; 310.0-860.0, 400.0-1,170.0, and 40.0-110.0 $\mu \mathrm{g}{ }^{-1}$ in Chrysichthys sp.; and 320.0-810.0, 400.0-3,970.0, and 30.0-300.0 $\mathrm{\mu g} \mathrm{kg-1}^{-1}$ (DEHP) in Synodontis sp., respectively. The values of 1,480.0-1,755.0, 2,025.0-2,705.0, and 255.0-480.0 $\mu \mathrm{g} \mathrm{L} \mathrm{L}^{-1}$, were recorded respectively for DEP, DBP, and DEHP in the water samples, while the concentration ranges of phthalates in the sediment samples are ND to $850.0 \mu \mathrm{g} \mathrm{kg}-1$ (DMP), 80.0-350.0 $\mu \mathrm{g} \mathrm{kg-1}$ (DEP), 190.0-1,420.0 $\mathrm{gg} \mathrm{kg}^{-1}$ (DBP), and 20.0-820.0 $\mu \mathrm{g} \mathrm{kg}^{-1}$ (DEHP).

\section{Sediment pollution}

Sediment acts as a sink for pollutants. Environmental contaminants such as hydrocarbons, heavy metals and pesticides have been known to have direct toxic effects when released into the aquatic environment (Forstner et al., 1998; Fleeger et al., 2003). There is a direct link between surface water and sediment contamination. Accumulated heavy metals or organic pollutants in sediment could be released back into the water with deleterious effects on 
human health. Adekola and Eleta (2007) have carried out studies on the heavy metal pollution of Asa River in Ilorin, Kwara state of Nigeria. The researchers reported metals in the concentration range of Mn (179.9-469.4 mg kg-1), Fe (1998.4-4420.4 mg kg-1) Cr (3.0-11.3 $\left.\mathrm{mg} \mathrm{kg}{ }^{-1}\right), \mathrm{Zn}\left(26.6-147.6 \mathrm{mg} \mathrm{kg}^{-1}\right)$ and $\mathrm{Cu}\left(1.9-13.3 \mathrm{mg} \mathrm{kg}^{-1}\right)$. Higher enrichment factors (EFs) were calculated for zinc, chromium, manganese and iron in the sediment samples. High values of EFs indicates anthropogenic source of contamination. Elevated levels of $\mathrm{Fe}, \mathrm{Ni}$ and $\mathrm{V}$ have been observed in the sediments of Iko River, a gas flaring station in the Niger Delta areas of Nigeria (Benson and Etesin, 2008). Contamination of sediments and fauna in aquatic ecosystems of Niger Delta by a wide range of toxic and bio-accumulative metals and hydrocarbons have been reported severally by Ebong et al. (2006), Udosen and Benson (2006) and Benson et al. (2007). In another study on the Lagos Lagoon carried out by Adeboyejo et al. (2011), the levels of OCPs in sediment were investigated from three stations along the Lagoon. The concentration in sediment $\left(\mu \mathrm{g} \mathrm{kg}^{-1}\right)$ ranged from ND to $2.96,0$ to 1.83, 0.62 to 43.54 , ND to 15.6, ND to 32.13, ND to 7.15, ND to 1.3 and 0 to 2.42 for aldrin, dieldrin, chlordane, endrin, endosulfan, heptachlor, $\mathrm{HCD}$ and $\mathrm{a}-\mathrm{HCH}$, respectively. The findings showed that these chemicals tend to bind with river's sediment particles with resultant effects on water pollution.

\section{Future management strategy for surface water quality monitoring in Nigeria}

At present, the monitoring of surface and ground water in Nigeria is carried out mostly by individual researchers in the Universities, Research Institutes, Government Agencies and some other organisations. The monitoring is haphazard, short term and based on individual interest and the reagents and equipment available to the Scientist. The monitoring is not properly coordinated and quality assurance programme is not incorporated in most of the studies. Therefore, comprehensive data on the water quality of major rivers in the Nigeria is not available. Recalling that water quality monitoring is a scientifically designed system of long-term, standardized measurement, systematic observation, evaluation and reporting of water quality in order to define status and/or trends, the need to improve the monitoring of the country's surface water cannot be overemphasised.

According to Whitfield (1988), the goals for water quality monitoring should be directed towards expansive information needs, determination of compliance within objective and standard framework, assessment of environmental trend and effects, mass transport estimation, and performance of general surveillance. It is therefore necessary to set up monitoring goals, which must be carried out with an appropriate sampling plan, where collected data could be periodically reviewed (Whitfield, 1988). All these procedures are lacking in the context of water quality in Nigeria.

The Federal Ministry of Water Resources and Rural Development was established in 1984 to among other functions, safeguard the water resource of the nation through periodic monitoring. The Federal Environmental Protection Agency - FEPA (established in 1988) which later transformed to the Federal Ministry of Environment also had the mandate of monitoring the environment of the country. The functions of FEPA also included regulation of effluents discharge by industries and several other Institutions. Statutory power was given to the Agency to prosecute any offender. The essence of this is to protect the water resource of Nigeria from pollution. 
Water quality degradation had been found most severe in Lagos, Rivers, Kano and Kaduna where most of the country's industries are located (Ekiye and Zejiao, 2010) with subsequent effects on public health and economic development (Ajibade, 2004, Adewolu et al., 2009). There is need for protection of water bodies in Nigeria as millions of the populace rely on it for daily water supply. The Federal Ministry of Environment must strengthen the present environmental laws such that the polluters of water bodies could be prosecuted. Industrial and agricultural sectors should also be compelled to treat their wastes before being discharged into the water bodies. Drastic measures must be taken by all authorities concern to minimize children morbidity and mortality due to poor sanitation and water quality problems.

There is an urgent need for the establishment of a National Water Monitoring Programme (NWMP) that will monitor the surface water of Nigeria. Quality Assurance Monitoring Plan (QAMP), which addresses quality control issues in detail, must be included in the monitoring programme. The water quality data that will be obtained from such a programme will be used to characterize waters, identify trends over time, identify emerging problems, determine whether pollution control programs are working, help direct pollution control efforts to where they are most needed, respond to emergencies such as floods and spills and also provide the regulatory community with baseline data needed to enforce environmental law.

In the USA, trained volunteers are monitoring the condition of their local streams, lakes, estuaries and wetlands. Environmental Pollution Agency encourages all citizens to learn about their water resources and supports volunteer monitoring because of its many benefits. Volunteer water monitors build community awareness of pollution problems, help identify and restore problem sites, become advocates for their watersheds and increase the amount of needed water quality information available on USA waters. A similar approach can be adopted in Nigeria. For example, a Directory of Environmental Monitoring Volunteers should be introduced using the National Youth Service Corps (NYSC) members ('Youth Corpers'). The young Science graduates that spend one year serving the country should be trained as Water Quality Monitoring Officers during their Orientation Programme. In addition, a special scheme to recruit young graduates as Water Quality Monitoring Officers should be introduced. The results of a comprehensive monitoring of our surface water on a weekly, monthly and quarterly basis will then be uploaded on a website. If the programme is adopted, quality data on our streams and rivers will be acquired.

In the light of new information and additional knowledge about the various environmental toxicants in the past two decades, there is an urgent need for a review of current environmental standards, regulations and laws in the country. The establishment of an Agency or a unit under the Federal Ministry of Environment that will enforce the laws and prosecute offenders cannot be over emphasised.

\section{Conclusion}

This paper has reviewed the water quality assessment and monitoring of surface water in Nigeria. The variation in water quality experienced in Nigeria reflects differences in land management and the physical environment. These differences occur both as a result of natural variability, societal development and pollutant inputs. In addition, water quality in the vicinity of urban areas is influenced by industrial and urban development. Understanding the condition of rivers and streams is critical if Nigeria is to develop effective 
plans to maintain, manage, and restore them. Water quality is affected in many ways. It changes with the seasons and geographic areas, even when there is no pollution present, therefore we must pay close attention to water quality by monitoring and testing. Like most other countries, the provision of quality water to the ever increasing population of Nigerians cannot be over emphasised. Without an adequate water supply, the millions of Nigerians will suffer, agriculture will be hampered, and the recreational industry will suffer. Therefore, a system that monitors the changing quality of the surface-water resources is highly necessary, and must be put in place by all Federal and State Agencies concerned. Water quality monitoring is therefore, pertinent for provision of data baseline that will be useful for policy makers and stakeholders to formulate policy that will favour protection and management of water resources. The issue of surface water pollution need to be addressed urgently by the Government to safeguard the public health.

\section{References}

$\mathrm{Abu}, \mathrm{G}$. O. and Egenonu, C. (2008). The current pollution status of the new Calabar River in the Niger Delta region of Southern Nigeria: A survey of antibiogram profiles of its bacterial isolates. African Journal of Environmental Science and Technology, Vol. 2, Issue 6, (June 2008), Pp. 134-14. ISSN 1996-0786.

Adebayo, O. T., Balogun, A. M. and Olubiyi, O. A. (2007). Chemical analysis of some industrial effluents that discharge into Lagos Lagoon, Nigeria. Research Journal of Environmental Sciences, Vol. 1, No. 4, pp. 196-199. ISSN 1819-3412.

Adeboyejo, O. A., Clarke, E.O. and Olarinmoye, M.O. (2011). Organochlorine Pesticide Residues in water, sediments, Fin and Shell-fish samples from Lagos Lagoon Complex, Nigeria. Researcher, Vol. 3, pp. 38-45. www.sciencepub.net/researcher/research0303/06_4630research0303

Adefemi, O. S., Asaolu, S. S. and Olaofe, O. (2007). Assessment of the physico-chemical status of water samples from major dams in Ekiti State, Nigeria. Pakistan Journal of Nutrition, Vol. 6, No. 6, pp. 657-659. ISSN 1680-5194.

Adekola, F. A. and Eleta, O. A. A. (2007). A study of heavy metal pollution of Asa River, Ilorin. Nigeria; trace metal monitoring and geochemistry. Environmental Monitoring Assessment, Vol. 125, No. 1-3 (October 2006), pp. 157-163. DOI: 10.1007/s10661-0069248-z.

Adeniyi, A., Dayomi, M., Siebe, P. and Okedeyi, O. (2008). An assessment of the levels of phthalate esters and metals in the Muledane open dump, Thohoyandou, Limpopo Province, South Africa. Chemistry Central Journal, Vol. 2, No. 9, (May 2008). DOI: 10.1186/1752-153X-2-9.

Adeniyi, A. A., Okedeyi, O. O. , Yusuf, K. A. (2011). Flame ionization gas chromatographic determination of phthalate esters in water, surface sediments and fish species in the Ogun river catchments, Ketu, Lagos, Nigeria. Environmental Monitoring and Assessment, Vol. 172, No. 1-4, pp. 561-9. ISSN: 0167-6369.

Adewara, S. O. and Visser. M. (2011). Use of anthropometric measures to analyze how sources of water and sanitation affect children's health in Nigeria. Environment for Development. Discussion Paper Series, (April 2011). 23p. EfD DP11-02.

Adewolu, M. A., Akintola, S. L., Jimoh, A. A., Owodehinde, F. G., Whenu, O. O. and Fakoya, K. A. (2009). Environmental threats to the development of aquaculture in Lagos State, Nigeria. European Journal of Scientific Research, Vol. 34, No 3, pp. 337-347. ISSN 1450-216X. 
Adeyemi, D., Anyakora, C., Ukpo, G. and Adedayo, A.and Darko, G. (2011). Evaluation of the levels of organochlorine pesticide residues in water samples of Lagos Lagoon using solid phase extraction method. Journal of Environmental Chemistry and Ecotoxicology, Vol. 3, No. 6, (June 2011), pp. 160-166. ISSN-2141-226X

Agbogu, V. N., Umoh, V. J., Okuofu, C. A., Ameh, J. B., Smith, S. I. (2006). Study of the bacteriological and physicochemical indicators of pollution of surface waters in Zaria, Nigeria. African Journal of Biotechnology, Vol. 5, No. 9, (May 2006), pp. 732737. ISSN 1684-5315.

Ahmed, K. and Tanko A. I. (2000). Assessment of water quality changes for irrigation in the River Hadejia Catchment. Journal of Arid Agriculture, Vol. 10, pp 89-94.

Aina, E. O. A. and Adedipe, N. O. (Eds.) (1996). Water Quality Monitoring and Environmental Status in Nigeria. FEPA Monograph 6, FEPA, Abuja, Nigeria, p239.

Ajao, E. A. and Anurigwo, S. (2002). Land - based sources of pollution in the Niger Delta, Nigeria. Ambio Journal of the Human Environment, Vol. 31, No. 5, pp. 442 - 445. ISSN: 0044-7447.

Ajibade, L.T. (2004). Assessment of water quality near River Asa, Ilorin, Nigeria. The Environmentalist, Vol. 24, No 1, pp. 11-18. DOI:10.1023/B:ENVR.0000046342. 65791.07.

Alatriste-Mondragon, F., Iranpourb, R. and Ahringa, B. K. (2003). Toxicity of di-(2-ethylhexyl) phthalate on the anaerobic digestion of wastewater sludge. Water Resources, Vol. 37, No. 6, (March 2003), pp. 1260-1269. Doi:10.1016/S0043-1354(02)00387-1

Arditsoglou, A. and Voutsa, D. (2008). Determination of phenolic and steroid endocrine disrupting compounds in environmental matrices. Environmental Science and Pollution Research, Vol. 15, No. 3, pp. 228-236. DOI: 10.1065/espr2007.12.459

Arimoro, F. O., Ikomi, R. B. and Osalor, E. C. (2007). The impact of sawmill wood wastes on the water quality and fish communities of Benin River, Niger Delta Area, Nigeria. International Journal of Science and Technology. Vol. 2, No. 1, pp. 1-12. web.firat.edu.tr/fenbilimleri/Dergiler/TJST/arsiv/.../1_\%20francis.pdf

Ayenimo, J. G., Adeeyinwo, C. E. and Amoo, I. A. (2005). Heavy metal pollutants in Warri River, Nigeria. Kragujevac Journal of Science, Vol. 27, pp. 43-50. ISSN 1450-9636

Benson, N. U., Essien, J. P., Williams, A. B., \& Ebong, G. A. (2007). Petroleum hydrocarbon accumulation potential in shellfishes from littoral waters of the Bight of Bonny, Niger Delta (Nigeria). Research Journal of Environmental Sciences, Vol. 1, No. 1, pp. 11-19. ISSN 1819-3412.

Benson, N. U. and Etesin, U. M. (2008). Metal contamination of surface water, sediment and Tympanotonus fuscatus var. radula of Iko River and environmental impact due to Utapete gas flare station, Nigeria. The Environmentalist, Vol. 28, No. 3, (May 2008), pp. 195-202. DOI: 10.1007/s10669-007-9127-3.

Bilotta, G. S and Brazier, R. E. (2008). Review: Understanding the influence of suspended solids on water quality and aquatic biota. Water Research, Vol. 42, pp. $2849-2861$. Doi:10.1016/j.watres.2008.03.018.

Blaso, C., Font, G. and Pico, Y. (2005). Analysis of pesticides in fruits by pressurized liquid extraction and liquid chromatography-ion trap-triple stage mass spectrometry. Journal of Chromatograph A, Vol. 1098, No 1-2, (December 2005), pp. 37-43. doi:10.1016/j.chroma.2005.08.037

Bouman, H. (2004). South Africa and the Stockholm Convention on Persistent Organic Pollutants. South African Journal of Science, Vol. 100, pp. 323-328. 
Calamari, D. and Naeve, H. (Eds.) (1994). Review of pollution in the African aquatic environment. CIFA Technical Paper No. 25, FAO, Rome, 118 pp.

CCME, (2008). Canadian Soil Quality Guidelines for the Protection of Environmental and Human Health: Benzo [a] Pyrene (1997). In: Canadian Environmental Quality Guidelines, 1999, Canadian Council of Ministers of the Environment, Winnipeg.

Dada, A.Y. (1997). Evaluation of Kano State Environmental Management Programme-1995 on industrial pollution: Case study of Challawa and Sharada Industrial areas, Postgraduate Diploma Dissertation, Department of Geography, Bayero University, Kano.

Diamanti-Kandarakis E, Bourguignon,J- P., Giudice, L. C., Hauser, R., Prins, G. S., Soto, M., Zoeller, R. T. and Gore, A. C. (2009). Endocrine-Disrupting Chemicals: An Endocrine Society Scientific Statement. Endocrine Reviews, Vol. 30, No. 4, (June 2009), pp. 293-342. ISSN Online 1945-7197.

Ekiye, E. and Zejiao, L. (2010). Water quality monitoring in Nigeria; Case Study of Nigeria's industrial cities. Journal of American Science, Vol. 6, No. 4, pp. 22-28. ISSN: 1545-1003.

Ebong, G. A., Ita, B. N., Nyong, A. B. and Benson, N. U. (2006). Seasonal changes in the water quality of Qua Iboe River Estuary and its associated creeks in Ibeno, Nigeria. Journal of Applied Sciences, Vol. 9, No. 2, pp. 6469-6482. eISSN: 1812-5662

Edet, A. and Worden, R. H. (2009). Monitoring of the physical parameters and evaluation of the chemical composition of river and groundwater in Calabar (Southeastern Nigeria).Environmental Monitoring and Assessment, 157, Issues 1-4, 243-258. ISSN: 0167-6369

Egborge, A. B. M. (1994). Water pollution in Nigeria - Biodiversity and Chemistry of Warri River. Ben Miller Books (Nig) Ltd.

Emoyan, O. O. (2009). Quantification and distribution of Polynuclear Aromatic Hydrocarbons (PAHs) in surface waters in the vicinity of Kokori Oil Field, Nigeria. Journal of Applied Science E Environmental Management, Vol. 13, No. 4. Pp. 39 - 42. ISSN 1119-8362.

Esoka PA and Umaru JM. (2006). Industrial effluent and water pollution in Kakuri area, Kaduna South, Nigeria. Journal of Industrial pollution and control, Vol. 22, No 1, pp. 93-100. ISSN 0970-2083.

Ezemonye, L. I., Ikpesu, T. O. and Tongo, I. (2009). Distribution of endosulfan in water, sediment and fish from Warri river, Niger delta, Nigeria. African Journal of Ecology, 48, No 1, pp. 248-254. doi/10.1111/j.1365-2028.2009.

Fatoki, O. S. and Ogunfowokan, A. O. (1993). Determination of phthalate ester plasticizers in the aquatic environment of south western Nigeria. Environment International, 19: 619-623.

Federal Government of Nigeria. (1988). Federal Environmental Protection Agency Decree 58, 1988, Federal Ministry of Information and Culture, Lagos, Nigeria.

FEPA (1991) Guidelines and Standards for Environmental Pollution Control in Nigeria. National Environmental Standards-Parts 2 and 3, Government Press, Lagos, pp: 238

Forstner, U., Calmano, W., Hong, J., and Kersten, M. (1998). Effects of redox variations on metal speciation. Waste Management and Research, Vol. 4, pp. 95-104.

Fleeger, J.W., Carmana, K.R., \& Nisbetb, R.M. (2003). Indirect effects of contaminants in aquatic ecosystem. Science of the Total Environment, Vol. 317, No. (1-3) (December 2003), pp. 207-233. Doi: 10.1016/S0048-9697(03)00141-4 . ISSN: 0048-9697. 
Galadima, A., Garba, Z. N., Leke, L., Almustapha, M. N. and Adam, I. K. (2011). Domestic water pollution among local communities in Nigeria - causes and consequences. European Journal of Scientific Research, Vol.52, No.4, pp. 592-603. ISSN 1450-216X.

Guruge, K.S. and Tanabe, S. (2001). Contamination by persistent organochlorine and butylin compounds in West coast of Sri Lanka. Marine Pollution Bulletin, Vol. 42, (March 2001), pp. 179-186. Doi:10.1016/S0025-326x(00)00140-5.|Harrod, T. R. and Theurer, F. D. (2002). Sediment. In: Haygarth, P.M., Jarvis, S.C. (Eds.), Agriculture, Hydrology and Water Quality. CABI, Wallingford, p. 502.

Heathwaite, L. (1994). Eutrophication. Geography Review, Vol. 7, No. 4, pp. 31-37.

Hjelmborg, P. S., Ghisari, M. and Bonefeld-Jorgensen, E. C. (2006). SPE-HPLC purification of endocrine disrupting compounds from human serum for assessment of xenoestrogenic activity. Analytical \& Bioanalytical Chemistry, Vol. 385, No 5, (July 2006) pp. 875-887. Doi: $10.1007 /$ s00216-006-0463-9

Ize-Iyamu, O. K., Asia, I. O. and Egwakhide, P. A. (2007). Concentrations of residues from Organochlorine pesticide in water and fish from some rivers in Edo state, Nigeria. International Journal of Physical Sciences, Vol. 2, No. 9 (September 2007), pp. 237-241. ISSN 1992-1950.

Izonfuo, L. W. A. and Bariweni, A. P. (2001). The effect of urban runoff water and human activities on some physico- chemical parameters of the Epie Creek in the Niger Delta. Journal of Applied Science and Environmental Management, Vol. 5, No. 1, pp. 4755. ISSN 1119-8362.

Jaji, M. O., Bamgbose, O., Odukoya, O. O. and Arowolo, T. A. (2007). Water quality assessment of Ogun River, South West Nigeria. Environmental Monitoring Assessment, Vol. 33, No 1-3, pp. 473-482. doi: 10.1007/s10661-006-9602-1. ISSN: 0167-6369

Kronvang, B., Laubel, A., Larsen, S. E., Friberg, N. (2003). Pesticides and heavy metals in Danish streambed sediment. Hydrobiologia, Vol. 494, No. (1-3), pp. 93-101. ISSN:1573-5117.

Lloyd, B. and Helmer, R. (1992). Surveillance of drinking water quality in rural areas. Longman Scientific and Technical, New York: Wiley, pp34-56.

Luks-Betlej, K., Popp, P., Janoszka, B. and Paschke, H. (2001). Solid-phase microextraction of phthalates from water. Journal of Chromatography A, Vol. 938, No. 1, (December 2011), pp. 93-101. Doi: 10.1016/S0021-9673(01)01363-2

Martin, J.C., Hoggart, C. and Matissa, A. (1998). Improvement priorities for sewage treatment in Latvian small and medium sized towns. Water Science Technology, Vol. 37, No. 8, pp. 137-144. ISSN Print: 0273-1223.

Mashi, S.A. and Alhassan, M. M. (2007). Effects of wastewater discharge on heavy metals pollution in Fadama soils in Kano City, Nigeria. Journal of Biomedical and Environmental Sciences. Vol. 20, No 1, pp. 70-77.

Mauricio, R., Diniz, M., Petrovic, M., Amaral, L., Peres, I., Barcelo, D. and Santana, F. (2006). A characterization of selected endocrine disruptor compounds in a Portuguese wastewater treatment plant. Environmental Monitoring Assessment, Vol. 118, No 1-3, pp. 75-87. Doi: 10.1007/s10661-006-0986-8. ISSN: 0167-6369

Mayon, N., Berrand, A., Lerroy, D., Malbrouck, C., Mandiki, S. N. M., Silvestere, F., Golffart, A., Thorme, J. and Kestemont, P. (2006). Multiscale approach of fish responses to different types of environmental contamination: A case study. Science of the Total Environment, Vol. 367, No 2-3, (August 2006), pp. 715-731. doi:10.1016/ j.scitotenv.2006.03.005. ISSN: 0048-9697 
Meinhardt, P. L. (2006). Recognizing waterborne disease and the health effects of water contamination: a review of the challenges facing the medical community in the United States. Journal of Water and Health, Vol. 4, suppl. 1, pp. 27-34. ISSN Print: 1477-8920.

Mustapha, M. K. (2008). Assessment of the water quality of Oyun Reservoir, Offa, Nigeria, using selected physico-chemical parameters. Turkish Journal of Fisheries and Aquatic Sciences, Vol. 8, pp.309-319. www.trjfas.org/pdf/issue_8_2/309_319.

National Bureau of Statistics. 2009. Social Statistics in Nigeria. 399 p. http:// www.nigerianstat.gov.ng/ext/latest_release/ssd09.pdf.Accessed: 10/10/2011.

Nwankwu, E. O. (1992). Microbial quality of Lagos lagoon water and important commercial fish species. In: Annual Report, Nigeria Institute for Oceanography and Marine Research, Lagos, pp. 37-38.

Nwilo, P.C. and Badejo, O. T. (2005). Oil spill problems and management in the Niger Delta. International Oil Spill Conference, (May 15-19, 2005), Miami, Florida, USA.

Obasohan, E. E., Agbonlahor, D. E. and Obano, E. E. (2010). Water pollution: A review of microbial quality and health concerns of water, sediment and fish in the aquatic African ecosystem. Journal of Biotechnology, Vol. 9, No. 4, (January 2010) pp. 423-427. ISSN 1684-5315.

Offiong, O. E. and Edet, A., (1996). Environmental pollution: water, land, air and noise in Cross River State. Technical Report submitted to Cross River Environmental Protection Agency, Calabar.

Ogunfowokan, A. O., Okoh, E. K., Adenuga, A. A. and Asubiojo, O. I. (2005). An assessment of the impact of point source pollution from a university sewage treatment oxidation pond on a receiving stream - a preliminary study. Journal of Applied Sciences, Vol. 5, No 1, pp. 36 - 43. Doi: 10.3923/jas.2005.36.43.

Ogunfowokan, A.O., Torto, N., Adenuga, A. and Okoh, E.K. (2006). Survey of levels of phthalate ester plasticizers in a sewage lagoon effluent and a receiving stream. Environmental Monitoring and Assessment, Vol. 118, pp. 457-480. ISSN: 0167-6369

Oguntoke, O., Aboderin, O. J, Bankole, A. M. (2009). Association of water-borne diseases morbidity pattern and water quality in parts of Ibadan City, Nigeria. Tanzania Journal of Health Research, Vol. 11, No. 4, 2009, pp. 189-195. ISSN: 1821-6404.

Olade, A. (1987). Heavy Metal Pollution and the need for monitoring: Illustrated for developing countries in West Africa. In: Hutchinson, T.C. and Meema, K.M. (eds.) Lead, Mercury, Cadmium and Arsenic in the Environment. John Wiley \& Sons Ltd, USA. pp. 335-341.

Olajire, A. A. and Imeokparia, F. E. (2001). Water quality assessment of Osun River: Studies on inorganic nutrients. Environmental Monitoring Assessment, Vol. 69: 17-28. ISSN: 0167-6369

Osibanjo, O., Daso, A. P. and Gbadebo, A.M. (2011). The impact of industries on surface water quality of River Ona and River Alaro in Oluyole Industrial Estate, Ibadan, Nigeria. African Journal of Biotechnology, Vol. 10, No. 4, (January 2011), pp. 696-702. ISSN 1684-5315.

Raji, M. I. O. and Ibrahim Y. K. E. (2011). Prevalence of waterborne infections in Northwest Nigeria: A retrospective study. Journal of Public Health and Epidemiology, Vol. 3, No. 8, (August 2011) pp. 382-385. ISSN 2141-2316

Solomon, U.U. (2009). The state of solid waste management in Nigeria. Waste Management Journal, Vol. 29, No. 10, pp. 2787 - 2790. 
Shukla, G., Kumar, A., Bhanti, M., Joseph, P.E. and Taneja, A. (2006). Organochlorine pesticide contamination of ground water in the city of Hyderabad. Environmental International, Vol. 32 (February 2006), pp. 244-247. doi:10.1016/j.envint.2005.08.027.

Taiwo, A. M. (2010). Environmental impact of poultry farm operations on Alakata Stream at Isolu in Abeokuta, Nigeria. Unpublished Master's Thesis. University of Agriculture, Abeokuta. 108 p.

Taiwo, A. M. (2011). Composting as a sustainable waste management technique in developing countries. Journal of Environmental Science and Technology, Vol. 4, No. 2, pp. 93-102. doi=jest.2011.93.102

Taiwo, A. M., Adeogun, A. O., Olatunde, K. A., Adegbite, K. I. (2011). Analysis of groundwater quality of hand-dug wells in peri-urban areas of Obantoko, Abeokuta, Nigeria for selected physico-chemical parameters. Pacific Journal of Science and Technology, Vol. 12, No. 1, (May 2011), pp. 527-534. www.akamaiuniversity.us/PJST12_1_527.pdf

Tatah, J. F. K. and Ikenebomeh, M. J. (1999). Influence of brewery effluent on heterotrophic counts and some physical parameters of Ikpoba Tropical River, Nigeria. Nigerian Journal of Microbiology, Vol. 13, pp. 55-58.

Udosen, E. D., \& Benson, N. U. (2006). Spatio-temporal distribution of heavy metals sediments and surface water in Stubbs Creek, Nigeria. Trends in Applied Sciences Research, Vol. 1, No. 3, pp. 292-300.Doi: 10.3923/tasr.2006.292.300

Water Initiative. (2010). UN water global annual assessment of sanitation and drinking water (2010 report). Implemented by World Health Organization. Geneva: United Nations.

http://www.who.int/water_sanitation_health/glaas/en/.Accessed January 2011

Wakawa, R. J ., Uzairu, A., Kagbu, J. A. and Balarabe, M. L. (2008). Impact assessment of effluent discharge on physico-chemical parameters and some heavy metal concentrations in surface water of River Challawa Kano, Nigeria. African Journal of Pure and Applied Chemistry, Vol. 2, No 9, (October 2008), pp. 100-106. ISSN 1996 0840.

Ware, G. W. and Whitacre, D. M. (2004). The Pesticide Book, 6th Ed. 496 pp. Meister Media Worldwide, Willoughby, Ohio. (ISBN 1892829-11-8).

Whitfield, P. H. (1988). Goals and data collection designs for water quality monitoring. Water Resources Bulletin, Vol. 24 No. 4, pp. 775-80. Doi: 10.1111/j.17521688.1988.tb00928.x. ISSN: 0043-1370

WHO. (2008). Guidelines for drinking water quality. $3^{\text {rd }}$ Ed. Health criteria and supporting information, Geneva.

WHO/UNEP (1997). Water Pollution Control - A Guide to the Use of Water Quality

Management Principles. In: Helmer, R. and Hespanhol, I. (eds). United Nations Environment Programme, the Water Supply \& Sanitation Collaborative Council and the World Health Organization. ISBN 0419229108.

http://www.who.int/water_sanitation_health/resourcesquality/wpccasestudy4.p df.

Yusuf, R. and Shonibare, J. (2004). Characterization of textile industries' effluents in Kaduna, Nigeria and pollution implications. Global Nest: the International Journal, Vol. 6, No 3, pp. 212-221. ISSN 1790-7632. 


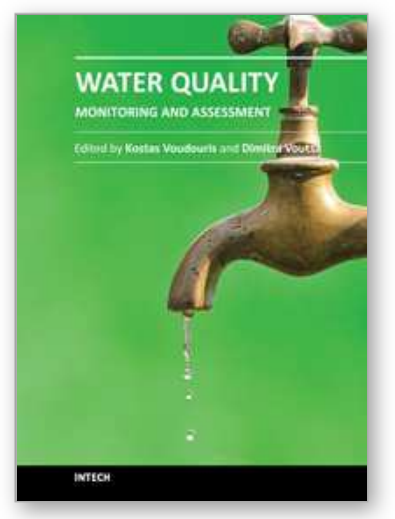

\author{
Water Quality Monitoring and Assessment \\ Edited by Dr. Voudouris
}

ISBN 978-953-51-0486-5

Hard cover, 602 pages

Publisher InTech

Published online 05, April, 2012

Published in print edition April, 2012

The book attempts to covers the main fields of water quality issues presenting case studies in various countries concerning the physicochemical characteristics of surface and groundwaters and possible pollution sources as well as methods and tools for the evaluation of water quality status. This book is divided into two sections: Statistical Analysis of Water Quality Data;Water Quality Monitoring Studies.

\title{
How to reference
}

In order to correctly reference this scholarly work, feel free to copy and paste the following:

A.M. Taiwo, O.O. Olujimi, O. Bamgbose and T.A. Arowolo (2012). Surface Water Quality Monitoring in Nigeria: Situational Analysis and Future Management Strategy, Water Quality Monitoring and Assessment, Dr. Voudouris (Ed.), ISBN: 978-953-51-0486-5, InTech, Available from: http://www.intechopen.com/books/waterquality-monitoring-and-assessment/surface-water-quality-monitoring-in-nigeria-situational-analysis-and-futuremanagement-strategy

\section{INTECH}

open science | open minds

\author{
InTech Europe \\ University Campus STeP Ri \\ Slavka Krautzeka 83/A \\ 51000 Rijeka, Croatia \\ Phone: +385 (51) 770447 \\ Fax: +385 (51) 686166 \\ www.intechopen.com
}

\author{
InTech China \\ Unit 405, Office Block, Hotel Equatorial Shanghai \\ No.65, Yan An Road (West), Shanghai, 200040, China \\ 中国上海市延安西路65号上海国际贵都大饭店办公楼 405 单元 \\ Phone: +86-21-62489820 \\ Fax: $+86-21-62489821$
}


(C) 2012 The Author(s). Licensee IntechOpen. This is an open access article distributed under the terms of the Creative Commons Attribution 3.0 License, which permits unrestricted use, distribution, and reproduction in any medium, provided the original work is properly cited. 